This item is the archived peer-reviewed author-version of:

Stylometric authorship attribution for the Middle Dutch mystical tradition from Groenendaal

\title{
Reference:
}

Kestemont Mike.- Stylometric authorship attribution for the Middle Dutch mystical tradition from Groenendaal

Dutch crossing : a journal of low countries studies - ISSN 0309-6564 - 42:3(2018), p. 203-237

Full text (Publisher's DOI): https://doi.org/10.1080/03096564.2016.1252077

To cite this reference: https://hdl.handle.net/10067/1391490151162165141 


\title{
Title:
}

Stylometric Authorship Attribution for the Middle Dutch Mystical Tradition from Groenendaal

\section{Author name}

Mike Kestemont

\begin{abstract}
The well-known medieval Groenendaal monastery in Brabant has produced some of the finest examples of medieval Dutch literature, including Jan van Ruusbroec's oeuvre, who together with Anne Frank, remains thé most frequently translated Dutch author of all time. Authorship attribution nevertheless remains a serious scholarly concern when it comes to the corpus of mystical texts from Groenendaal: because of the general proximity of the Groenendaal authors, their oeuvres can be difficult to delineate. In this paper, I apply a quantitative, style-based methodology for authorship attribution to a sizable corpus of Groenendaal authors. These computational techniques are borrowed from the innovative field of stylometry in the Digital Humanities. I will discuss how the experimental results obtained are able to confirm and complement many of the authorship-related hypotheses developed in traditional Middle Dutch studies. Additionally, this work hopes to demonstrate the exciting scholarly potential of 'Distant Reading' for the study of the rich textual heritage from the medieval Low Countries.
\end{abstract}

\section{Keywords}

Middle Dutch religious literature, Jan van Ruusbroec, Mysticism, Stylometry, Computational Authorship Attribution

\section{Introduction}

The well-known medieval Groenendaal monastery in Brabant has produced some of the finest examples of medieval Dutch literature. Texts by famous authors such as Jan van Ruusbroec are still widely read and studied across the globe and have become a central part of the canon of historical Dutch literature. Together with Anne Frank, Ruusbroec is for instance thé most frequently translated Dutch author of all time. Apart from Ruusbroec, Groenendaal was also home to a number of other influential mystical vernacular authors, such as Jan van Leeuwen, who are nowadays often considered key figures in the history of European mysticism, not in the least because their works have often known a sizable reception outside the Low Countries. The Groenendaal monastery can therefore be characterized as one of the most influential as well as dense networks of Middle Dutch authors and texts.

Precisely because of the proximity of the authors and texts from the Groenendaal monastery, authenticity criticism, and authorship attribution in particular, remain a major scholarly concern. ${ }^{1}$ The exact delineation of Ruusbroec's oeuvre, for instance, remains controversial up to the present day. In this paper, I will apply a modern, quantitative methodology for authorship attribution to a sizable corpus of some of the main Groenendaal authors. This innovative approach is borrowed from the domain of computational text analysis in the Digital Humanities, and more specifically from the relatively young discipline of computational stylistics or stylometry. ${ }^{2}$ Stylometric authorship attribution has not become mainstream yet in the study of (medieval) 
literature, although it certainly seems to have been gaining traction in the recent study of Dutch literature. ${ }^{3}$

The present case study is an interesting test case when it comes to computational authorship attribution. To begin with, the works studied deal with highly similar mystical topics. They discuss complex religious matters in fairly obscure wordings, that can even be hard to grasp for human experts, let alone for modern readers with no specialist background. ${ }^{4}$ Additionally, most of these texts - as well as the oldest manuscripts containing them - originate from the same monastic setting: namely, the Groenendaal monastery in the second half of the fourteenth century. Many of the authors discussed must have known each other well and must have studied each other's works closely. The influence of Ruusbroec is even so prominent in the texts of some of his disciples that some of their work has been erroneously attributed to Ruusbroec himself until well into the past century. In spite of these challenges, I hope to demonstrate the - at times surprising - effectiveness of stylometry for the discrimination of authorial styles in this corpus.

\section{A Master in the Middle}

Due to the many English-language editions, translations and studies published in recent decades, there has been a serious increase in the international scholarly attention for the Middle Dutch mystical tradition. ${ }^{5}$ Jan van Ruusbroec clearly stands out among his contemporary and present-day peers: together with Anne Frank, Ruusbroec is thé most frequently translated Dutch author of all time. ${ }^{6}$ Born in 1293, Ruusbroec retired as a chaplain from the Church of Saint Gudule in Brussels in 1343. Together with two kindred spirits, he withdrew to the Sonian Forest on the edge of the city and founded a small heritage there, called Groenendaal ('Green Valley'). This self-sufficient community would adopt the Rule of Saint-Augustine in 1350 and the Augustinian priory would in later centuries become one of the main religious centers in Brabant. Ruusbroec showed himself a charismatic spiritual leader in Groenendaal, as well as a welcoming host for (international) visitors, such as the well-known Johannes Tauler. Already during his lifetime, Ruusbroec became famous as the author of a series of influential religious treatises in the Middle Dutch vernacular. When Ruusbroec died in 1381, the community had already started to stimulate and streamline the dissemination of authorized versions of Ruusbroec's works.

Ruusbroec's complex oeuvre deals with contemplative theology and centers around the mystical theme of the spiritual encounter of the human person and God. He believed that all human beings originally emanated from God (exitus) and that they therefore had a natural tendency to return to him (reditus). ${ }^{7}$ Human beings could realize this process of continuous mystical unification in a threefold manner: in the "outer", working life, the "intimate", spiritual life and the "seeing", contemplative life. This unusual synthesis of an active, engaging attitude and a passive, contemplative one is an important feature of Ruusbroec, which also sets his learning apart from that of many contemporary medieval mystics, many of whom favoured an ideal of passive contemplation over labour and activity. Ruusbroec's ideal of a "common life" (ghemeyne leven) or the life in communion with Christ has to be realized via a combination of enjoyment and activity (ghebruken ende werken). Among scholars, there is currently wide-spread acceptance for the attribution of 11 major tractates to Ruusbroec (mostly in prose), all of which will be included in this 
study (Table 1). ${ }^{8}$ Ruusbroec started writing in Brussels already, but because the chronology of his oeuvre is difficult to establish, it remains unclear which exact share of his oeuvre was already completed when he left the city centre for Groenendaal.

\section{[Table 1]}

In his recent acclaimed literary history of fourteenth-century Middle Dutch literature, Frits van Oostrom has characterized Ruusbroec as a "master in the middle", not only because of his moderate attitude in spiritual matters, but also because of the series of interesting fellow-writers amongst which he lived in Groenendaal. ${ }^{9}$ In his well-known survey monograph, McGinn even spoke of the Groenendaal community as the "school of Ruusbroec". ${ }^{10}$ In our initial sections, we will contrast Ruusbroec's oeuvre with that of Jan van Leeuwen (died 1378). ${ }^{11}$ Leeuwen was perhaps the best known of Ruusbroec's disciples, not in the least because of his remarkable profession: ca. 1344 he entered into the profession of cook in the Groenendaal community. Sources therefore typically address Leeuwen as Ruusbroec's 'good cook' (bonus cocus). Leeuwen's writing style has been characterized as spontaneous, unstable, appositional and even chaotic, with many of the texts apparently left unfinished. Famous highlights from his oeuvre include his renouncement of the teaching of Master Eckhart. Equally striking is the vivid passage in which Leeuwen dramatically describes how, one night, he was seduced by a woman and nearly kissed her, driven by his 'sick bodily urges'. ${ }^{12}$ In total, Leeuwen is known to have authored 22 religious tractates, all of which will be included in our study (Table 1). In Leeuwen's writings too, the balance between the active and spiritual life plays a major role.

Ruusbroec's influence is considered dominant throughout Leeuwen's oeuvre at many levels. Interestingly, Leeuwen's writings primarily survive from a small number of manuscripts which must have been 'edited' in a number of stages by some his fellow brothers at Groenendaal. ${ }^{13}$ Moreover, there exists a worry among some scholars that various secretaries and editors might have interfered with the general style in Leeuwen's writings as they have come down to us, perhaps even applying some mild censure. ${ }^{14}$ Leeuwen called himself "illiterate" which indeed raises questions as to what extent he could have functioned as a fully independent writer. An authoritative study has suggested that Ruusbroec himself might have acted as the first 'editor' of the earliest compilation of Leeuwen's tractates. ${ }^{15}$ This is all the more striking, because excerpts of this early tractacte collection in some manuscripts survive amongst Ruusbroec excerpts, and modern scholars have even wondered whether Ruusbroec should not be considered the tractates' author altogether. ${ }^{16}$ From the point of view of authorship attribution, it is therefore a challenging question whether Leeuwen's writings will form a coherent set of works on the stylistic level, and perhaps even more so, whether this set can be accurately distinguished from Ruusbroec's works. As a test case, we will first attempt to distinguish the writing styles of Ruusbroec and Leeuwen below. Only afterwards, we will move on to a number of disputed works that survive from Ruusbroec's circles. In the following section, we will first survey the field of computational authorship attribution.

\section{Computational Authorship Studies}

Authorship studies are an important problem in computational stylistics or stylometry, where the writing style of (literary) texts is nowadays studied via quantitative methodologies, borrowed from fields outside the traditional Humanities, such as 
Statistics, Computational Linguistics and even Artificial Intelligence. ${ }^{17}$ Stylometry can be considered a part of the international initiative of Digital Humanities, where scholars explore how computational methodologies and digitization can complement and enhance traditional scholarly practices in the Humanities. A defining characteristic of stylometry is that it is concerned with the relationship between the writing style of texts and meta-information related to texts, such as publication date, authorship, literary period, etc. In the subfield of 'stylochronometry', for instance, scholars try to date texts on the basis of stylistic characteristics. ${ }^{18}$ Because stylometry does not essentially depend on the actual reading of texts, it is often said to be a form of 'Distant Reading' or even 'Not-Reading', in order to distinguish it from more traditional forms of close reading in the Humanities. ${ }^{19}$ In reality, stylometry is often used as a tool to generate serendipitous discoveries: via the relatively blunt 'macroanalysis' of large corpora, researchers attempt to single out interesting outliers that seem to be interesting for further study, e.g. via close reading.

Undoubtedly, authorship attribution is currently one of the primary applications of stylometry. Researchers in this fields are guided by the assumption 'that by measuring some textual features we can distinguish between texts written by different authors'. ${ }^{20}$ Although such a general claim is obviously tendentious, many empirical studies have demonstrated that computational analyses can often distinguish between works by different authors based on differences in writing style. Such methodologies are naturally a welcome aid in the authenticity criticism of medieval literature, in which anonymous and pseudonymous texts abound, and for which scholars still heavily rely on labour-intensive interpretative forms of study, including e.g. detailed source criticism. The prominence of function words in present-day stylometry is an interesting complement to traditional methods. While function words have been used in the past to characterize authorial styles, for instance in classical studies, these analyses have typically remained extremely selective, and thus biased and small-scale because of the considerable manual effort involved. ${ }^{21}$

Apart from the focus on quantification, present-day authorship studies in stylometry can be easily distinguished from more traditional forms of stylistic authorship attribution, because of their exceptional emphasis on function words in texts (articles, prepositions, pronouns, etc.), rather than more complex, content-related stylistic features, such as uncommon syntactical constructions or rare nouns. ${ }^{22}$ While the latter have often been used in historic authorship studies, stylometrists now agree on the superiority of the former for a number of reasons. Function words are highly frequent throughout texts: all authors writing in a similar era and language simply have to resort to the same set of function words - it is impossible to write an English text without definite articles. This makes function words an attractive base for statistical comparison. Function words are moreover semantically bleak: they do not carry a lot of meaning in isolation. This implies that function words are to some extent independent of the specific content of texts, since the topic of a text might not have a significant impact on the function words used in texts. This aspect is especially promising, since it renders more feasible the study of authorial style across different topics and genres.

A major methodological advantage is that function words do not attract attention to themselves: psycholinguistic reading research indeed demonstrates that humans do not process function words in a very conscious manner. Because of their merely 
structural, grammatical function, humans seem to take them for granted to some extent. This characteristic has a lot of potential in the context of malignant forgery and imitation, for instance, with respect to authors working in the same tradition or workshop, which is not uncommon in medieval literature. ${ }^{23}$ Writers copying another author's writing style will be inclined to focus on conspicuous stylistic features which, at least to the human eye, seem characteristic for the style which (s)he is trying to reproduce. It can be expected that function words will be more robustly insensitive to imitation, whereas methodologies that focus on more striking characteristics will have a hard time distinguishing his master's voice from that of epigones. An interesting parallel for this idea can be found in art history, where centuries ago already, Giovanni Morelli (1816-1891) advocated that attribution in paintings should not be based on the semantic features of a painting (e.g. composition, colour schemes, ...), because these characteristic are too strongly dependent on historical trends or preferences within (a group of) workshops. ${ }^{24} \mathrm{He}$ argued that attributions should be based on paintings' functional elements, such the ears, hands, feet, etc. of the people portrayed. While Morelli's ideas have not gone uncriticized in art history, they provide an interesting illustration of the surplus value of function words.

Despite these fascinating characteristics, one should note that the use of function words for authorship attribution is not always entirely unproblematic. First of all, we should remain aware that not all languages use function words to the same extent to express linguistic structure. Latin is the school book example of a more heavily inflected language in which word endings might also play a more important role which is currently under-studied in stylometry. Secondly, it should be stressed that function words cannot be claimed to be completely content-independent: studies have shown that texts in different genres can display clearly divergent distributions of function words, which naturally calls for caution. Narrative perspective is for instance an aspect of a text that has a strong impact on the pronouns used in a text, which is why e.g. personal pronouns are often excluded or 'culled' from authorship analyses. Finally, one should also remain aware that stylometry adopts a notion of 'style' that is quite different from the conceptions of style in traditional literature. Whereas stylometry tends to favour all less conscious aspects of style, stylistic analyses in traditional studies have typically focused on the contrary, which might cause confusion.

\section{Textual Variation}

Researchers in medieval stylometry have long recognized that the application of computational techniques to medieval literature is not straightforward. ${ }^{25}$ This is mainly due to the multitude of alterations to which texts were subject during their transmission. Medieval texts rarely survive in autograph manuscripts, and mostly, texts have only come down to us in younger copies (often of earlier copies), produced by a long chain of subsequent scribes. As discussed by influential theorists such as Angus McIntosh, medieval scribes interacted with their exemplars during this transmission process: their copies typically formed a compromise between their own language, stylistic habits, cultural mindset, etc. and that of their exemplars. ${ }^{26}$ Scribal behaviours have thus been attested, ranging from fairly literal copying to extremely free 'translations', so to speak. Scholars commonly distinguish, on the one hand, "substantive" textual variation (e.g. word-level adjustments affecting semantics or writing style) and, on the other hand, less substantive or "accidental" alterations. The latter include the seemingly much more "innocent" interventions by scribes, e.g. on 
the level of dialect or orthography. From the point of view of authorship attribution, both types of variation are worrying.

Let us begin with the accidental variation, which poses a very practical problem: in many texts, subsequent scribes have introduced superficial, linguistic variations on the level of dialect and orthography, leading to considerable spelling and spacing inconsistencies within the same text, as well as across different texts. This is challenging for computer applications since this situation renders the automatic identification of words all but straightforward. Even the slightest disagreement in spelling (e.g. a common allographic pair such as $u$ vs. $v$ ) will cause a matching algorithm to consider geuen and geven ('to give') as two completely unrelated Middle Dutch words. Therefore, it is dangerous to compare medieval texts in unnormalized versions. A seminal paper in medieval stylometry indeed showed that "out-of-thebox" computational authorship attribution techniques are much better suited for scribal attributions than authorial attributions. ${ }^{27}$

For the present research, I have therefore attempted to normalize as much as possible the spelling variation encountered in the multifarious editions in the Groenendaal corpus. To this end, I have used an automated software component called a 'taggerlemmatizer'. Such a tool takes a raw Middle Dutch text as input and outputs it in an enriched format with a part-of-speech tags and lemmas added to the words. Part-ofspeech tagging is a well-studied task in computational linguistics, whereby a sequence-aware piece of software attempts to assign a grammatical category to words, on the basis on its lexical context. ${ }^{28}$ Some examples: 'V(fin,pres,aux-cop)' indicates a finite form of an auxiliary verb or copula in the present tense; ' $\operatorname{Adp}()$ ' indicates an adposition; 'Pron(pers, 3 ,sing)' indicates a form of the third person singular personal pronoun. The tagger-lemmatizer additionally assigns a present-day headform or lemma to each token in the input text based on its previously assigned part-of-speech tag. The historical spelling variants part, pard, paert, pairt, etc. are all assigned the present-day lemma 'paard' (= 'horse'). ${ }^{29}$

A tag-lemma pair helps to identify Middle Dutch words, ignoring differences between tokens that only differ in spelling or inflection. The tagger-lemmatizer we use has been trained on a large and representative annotated corpus of Middle Dutch texts: from this material the software has been able to learn, and generalize its behaviour in order to be able to output annotations for new, unseen Middle Dutch texts. The tagger-lemmatizer is described in more detail in a forthcoming publication. Below, I offer examples of the annotation which was outputted for the famous beginning of Ruusbroec's Espousals. Note that the output of this system is far from flawless as could be expected: especially content words can be relatively harder to analyze correctly for the tagger. The tagger, for instance, fails to correctly tag siet and comt as imperatives (although it gets the lemma right). Luckily, the tagger-lemmatizer has far less trouble correctly analyzing the function words that will be at stake in this paper.

\section{[Table 3]}

Even if we are able to significantly reduce the accidental variation in the corpus, we still face the substantive alterations which might have been introduced by subsequent scribes. These form a major impediment, especially if these alterations can be considered corruptions with respect to the authorial original. On numerous occasions I 
have expressed concerns with respect to this situation myself. Is it really methodologically justified to apply stylometry to medieval prose texts, if we can never be truly sure which textual characteristics in a text are authorial rather than scribal $?^{30}$ For authorship studies we can of course resort to critical editions that approximate as closely as possible the authorial original. Nevertheless, in the absence of complete manuscript traditions, such critical editions will of course never be entirely reliable.

In previous research, I have attempted to bypass this problematic situation by applying stylometry to the rhyme words in medieval texts. It is often claimed that rhyme words are a relatively stable element in the transmission of both oral and written (medieval) texts. ${ }^{31}$ These words formed the bare skeleton of rhymed texts and, apart from perhaps their spelling, they seem to have been difficult to change for scribes, without them having to rewrite long parts of the text. Rhyme words are thus very likely to reflect authorial, rather than scribal style. In a series of studies, I have demonstrated that stylometric techniques can indeed be applied to rhyme words for a variety of case studies in Middle Dutch literature - a tradition in which an absolute majority of literary texts has been written in rhymed couplets. ${ }^{32}$

While the restriction to rhyme words has proven to be a useful methodological 'trick', it has obvious limitations, since the technique can only be applied to rhymed texts, preferably of a considerable length. Unfortunately, the technique is entirely useless for the (shorter) prose texts in which medieval traditions in Europe typically abound. In this paper I wish to explore whether it is indeed a priori impossible to apply stylometry to medieval prose texts. I hope to be able to relax some of my previous claims, showing that stylometry can indeed yield valid attribution results - at the very least for the corpus of texts under scrutiny here. When it is applied cautiously and in a respectful, yet creative dialogue with previous philological research, I will argue that stylometry is able to yield useful attribution hypotheses, which surprisingly often reenforce traditional research results. Of course, it should be emphasized it will never be possible to completely extrapolate these findings to other languages, traditions, genre and case studies, of which the present case study is not necessarily representative.

\section{Cluster Analysis}

Today, stylometrists have a number of well-established techniques at their disposal. In this paper I will introduce three of them: Hierarchical Clustering, Bootstrap Consensus Trees and Principal Components Analysis. ${ }^{33}$ These techniques share a number of important characteristics. First of all, these are "multivariate techniques", meaning that we can use them to compare texts with respect to multiple word frequencies simultaneously. Modeling complex correlations between word frequencies offers an important advantage to more naïve (e.g. bivariate) techniques that can only consider a limited number of words at the same time. Secondly, these techniques can output intuitive visualisations, such as dendrograms or scatterplots, which allow us to assess the outcome of experiments in an intuitive manner. Thirdly, these three algorithms are all "unsupervised": this implies that we can feed them the textual data without having to provide any pre-existing hypotheses about the structure in the data - i.e. we can let the data "speak for itself". For the sake of brevity, I will 
attempt to bypass as much as possible the mathematical details of the procedures used.

In this section, I will demonstrate the working of these techniques by applying them to the two large (and relatively undisputed) oeuvres by Ruusbroec and Leeuwen. After this demonstration, I will move on to the analysis of two disputed texts. Fig. 1 offers a dendrogram which has been generated by a hierachical cluster analysis (henceforth HC). ${ }^{34}$ Each of the leaf nodes in this tree represents one the texts compared ( 22 by Leeuwen and 11 by Ruusbroec). These leafs have been coloured (in green or red) according to their authorship, although the analysis itself does not have access to this information. Conceptually speaking, an $\mathrm{HC}$ attempts to find meaningful clusters in the data in a "bottom-up" fashion. First, the two most similar texts are joined and merged into a new node at a slightly higher level in the tree. Next, the HC will scan the corpus for the next two most similar nodes and join these. As such, the algorithm will iteratively work its way up the tree, until finally all nodes have been merged. A dendrogram like the one in Fig. 1 displays the distance between nodes on the horizontal axis: if two nodes are highly dissimilar, they will only be joined "more towards the left". As can be gleaned from Fig. 1, the HC has detected two major clusters in the corpus: the texts by Ruusbroec are far more similar to each other than to Leeuwen's texts. These are therefore merged at a much earlier node during the construction of the three. Indeed, the nodes overarching our two authors' oeuvres are only connected in the final stage by the top node.

\section{[Fig. 1]}

Fig. 1 immediately illustrates the considerable potential of multivariate statistics for the unsupervised attribution of medieval prose texts. However, we should elucidate one more aspect, which is of course key to the success of the HC procedure: its notion of "stylistic (dis)similarity". Before applying the $\mathrm{HC}$, we have to represent our data in a numerical format which can be quantitatively processed. For our corpus, this format takes the form of a frequency table in which each row represents one of the texts in the corpus and each column represents a word. Each cell in this table gets populated by a particular word's relative frequency in one of texts (i.e. the ratio of the word's absolute frequency to the entire text's length). Such a frequency table can thus be likened to an extremely large and dense two-dimensional data table in a spreadsheet application. It is crucial, however, that we do not include every single item from the corpus's vocabulary in this table: as explained above, we have good methodological reasons to limit our text representation to the frequencies of function words in the texts and simply remove all frequency columns for non-function words. This might seem like a coarse simplification of the textual reality in our corpus, but here we will show that this modeling act in fact makes our data much more suitable as input for authorship attribution algorithms.

How do we decide which words to keep in our text representation? It is common to simply rank all the words in the corpus according to their overall, cumulative frequency. There exists a well-known regularity in corpora that this approach will rank at the top those high-frequency function words in a language which are least bound to specific semantic contexts, topics, genres etc. In Table 3, we have listed the top part of the ranking for the lemmas assigned to the words in our corpus. ${ }^{35}$ At the top we can indeed find the lemmas of typical function words, such as the coordinating 
conjunction en (Middle Dutch ende, meaning 'and'), which are common in all texts. We should stress, however, that we have carefully removed a large number of words from the corpus, in spite of their high ranking in this list. This is a common "culling" strategy in stylometry whereby we attempt to remove frequent, yet context-specific words (especially nouns, adjectives and verbs). We have manually gone through the first 700 words in the list and removed all potentially disturbing words (marked with a hashtag in Table 3), which left us with ca. 144 words that cannot easily be linked to a specific topic or genre, allowing us to focus on authorial writing style instead. Additionally, we have also removed all personal pronouns from the data (marked with an asterisk): while, strictly speaking, these are of course function words, previous research has demonstrated that these words are often strongly tied to e.g. genre (cf. narrative perspective). Such artefacts render it difficult to study authorial styles across different text varieties, which is why it is generally safer to remove them from the analysis. In general, our selection is therefore restrictive rather than inclusive.

\section{[Table 3]}

In the end, our representation of a text will contain a list or "vector" containing 144 numeric values, i.e. the relative frequency of each selected word in each text. To these values we now can apply fairly standard distance metrics such as the Euclidean distance metric or the Manhattan distance, which some of us might recall from mathematics courses. In stylometry it is nowadays common to use "Burrows's Delta", an elegant metric to estimate the stylistic distance between two texts, for instance, during the $\mathrm{HC}$ which we discussed above. ${ }^{36}$ Apart from looking at the actual frequency differences between two texts, this metric will weigh these differences by looking at the standard behaviour of words throughout the entire corpus under scrutiny. Although, mathematically speaking, Burrows's Delta is a rather simple distance metric, it has been proven to display a solid performance in empirical studies. Throughout this paper, we will use Delta as our standard distance metric.

The HC introduced above has a number of parameters and settings which we can tweak and tune. An important setting concerns sampling: in Fig. 1 we have compared entire texts: this approach has two major disadvantages. First of all, Table 1 shows that the texts in our corpus vary widely in length. Methodologically speaking, it might be safer to compare texts of the same length (although we work with relative frequencies). Secondly, we treat texts as atomic units in this approach. This entails that we have no way of assessing the internal stylistic consistency of the texts analyzed. It can be expected that voluminous texts such as Ruusbroec's Tabernable (over 116,000 lemmas) might show internal stylistic differences: tools to help detect these would of course be more than welcome. In this paper we will therefore sometimes draw "samples" from texts, or non-overlapping, fixed-size slices of texts, leaving out any words at the end of text that cannot fill an entire new slice anymore.

Another important parameter of the HC is the number of words (lemmas in our case) to which the procedure is applied. In this paper we will often work with the selection of 144 MFW described above, although it can be worthwhile to change this parameter: cluster analyses, for instance, have been reported to yield unstable results in some cases where different numbers of high-frequency words are analyzed. Bootstrap Consensus Trees (BCT) are therefore often used as a complement to traditional $\mathrm{HC}$ : under the hood, this technique will run a number of cluster analyses 
based on different sets of high-frequency words. ${ }^{37}$ Afterwards, it will output an (unrooted) dendrogram that summarizes the results of all the cluster analyses, ignoring nodes which did not occur in at least $50 \%$ of the analyses. (Scholars in medieval stemmatology might recognize such dendrograms from computational phylogeny.) The main advantage is that this technique will thus analyse several frequency bands independently and, in the end, might yield more stable results. Fig. 2 shows an example of a BCT for the previously analyzed texts by Ruusbroec and Leeuwen. ${ }^{38}$ Clearly, the stylistic distinctions between both authors are well reflected in the tree structure, and thus seem to be obvious as well as consistent across different sets of high-frequency function words.

\section{[Fig. 2]}

For Leeuwen, an additional experiment is worthwhile. In their authoritative study of the earliest reception of Leeuwen's oeuvre, Geirnaert and Reynaert have expressed serious concerns as to which extent we can characterize Leeuwen as an independent author, whose oeuvre survives in an unmediated form. Leeuwen's opera omnia seem to have been collected and published by the Groenendaal community in three subsequent stages before 1420: first, they collected a series of five tractates (which I shall refer to as 'Le1'):

- Vanden drie koninghen (DK)

- Van tienderhande materien (TM)

- Een ghetughe (G)

- Redene ende ondersceyt (RO)

- Van vijfterhande bruederschap (VB)

Next, they would have extended this collection with four new tractates (Le2):

- Vanden tien gheboden gods (TG2)

- Dboec vander bedinghen (BB)

- Dboec vanden inval (BI)

- Die rolie vander woedegher minnen (Rolie)

The final extension contained the remaining 13 texts that survive by Leeuwen (Le3) and mainly covered unfinished and more controversial work. About these early Groenendaal editions, Geirnaert and Reynaert note (I quote them in my own translation):

Even if one were not to go as far as to suppose that Leeuwen's works were rewritten from the very beginning onwards by (an)other person(s), or that the monastery would have put a secretary at this disposal as a sort of ghostwriter, it is clear already that Groenendaal had a firm hand in the earliest dissemination in written form. For the first "edition" [i.e. Le1] Ruusbroec comes to mind, for the second edition [i.e. Le2], Jan van Schoonhoven [a local Groenendaal monk]. ${ }^{39}$

Based on these suggestions, one could hypothesize that Leeuwen's oeuvre might show a threefold stylistic structure corresponding to these subsequent publication phases, especially if these editions were carried out by different secretaries, such as 
Ruusbroec. The reworking or streamlining of Leeuwen's oeuvre by different people might have compromized its stylistic coherence or integrity. In the stylometric literature, a number of case studies have demonstrated that quantitative techniques are sometimes able to detect by which editor or secretary text were edited. ${ }^{40}$

I have carried out numerous analyses (for different sample sizes, MFW, techniques etc.) of Leeuwen's oeuvre, of which a typical example is plotted in Fig. 3. Surprisingly, in none of these analyses I was able to discern the threefold stylistic structure which might have been expected on the basis of the study by Geirnaert and Reynaert. While some of the texts from the first publication phase indeed form clusters (such as $V B, G$ and $R O$ from Le1), the texts from the three stages mingle and cluster on the basis of content (e.g. TG and TG2 are in the same clade, both decalogical tractates), rather than publications phase. These observations justify the question whether Leeuwen's writings, at least when viewed from a stylistic macroperspective, were indeed as heavily reworked as some scholars have feared in the past. Leeuwen's texts for instance rarely show advanced stylistic similarities to Ruusbroec, of which Leeuwen was an undeniable epigone, who has been suggested as a candidate-editor for the first edition of Leeuwen's works. For the present study, on the other hand, the stylistic integrity and uniformity of Leeuwen's oeuvre is reassuring.

\section{[Fig. 3]}

\section{Principal Components Analysis}

The third and last statistical technique we will use here is Principal Components Analysis (PCA). The typical output of a PCA in stylometry is a two-dimensional scatterplot like the one graphed in Figure 4, again including the texts by Ruusbroec and Leeuwen. ${ }^{41}$ From these texts we drew samples of 2,476 lemmas (the size of the smallest text included, Leeuwen's $A M$ ). A PCA also takes as input the relative frequency vectors introduced above. Based on this frequency information, it will attempt to plot the texts as points in a two-dimensional space (here texts are plotted as little symbols, one per author), while retaining as much of the original information as possible. This means that the PCA will try to plot similar texts closer to each other in the scatterplot, while maximizing the distance between clouds of dissimilar texts. When applied to high-frequency function words in texts, it has been noticed that PCA tends to group texts based on their authorship. This regularity also is evident from our Fig. 4, where Ruusbroec's texts cluster on the far right side of the scatterplot, whereas Leeuwen's texts form a cloud to the far left.

\section{[Fig. 4]}

The left-right opposition in this PCA plot in technical terms coincides with the first and most important "component" of the analysis, meaning that the horizontal dimension in the scatterplot represents the main variation present in the data. In our case, this component clearly corresponds to the authorial signal with, indeed, a close to perfect authorial separation of the samples. A primordial advantage of PCA is that it offers an intuitive way to inspect on which specific words the scatterplot is based. The cluster trees discussed so far are very useful to visualize large data sets, potentially with many authors and texts included. Nevertheless, these visualizations sometimes tend to function as black boxes, because the analyses do not reveal on 
which specific groups of words a specific clustering is based. With PCA, the loadings of individual words can be plotted, in order to gain insight into which words have caused a particular visualization.

In Fig. 5, we have plotted the same analysis as in Fig. 4, but we have added the "word loadings" in black. Additionally, the original texts are no longer plotted as little symbols: rather a text's title (in lightgrey) is used to indicate a sample's position. Of course, such visualizations sometimes can make a highly cluttered impression. Nevertheless, they offer an important aid in the interpretation of plots. An excellent example are the word loadings to the far left, which because of this extreme position can be considered typical of Leeuwen's works, which are also found to the far left of the plot: ook ('too'), nog ('also'), meer ('more'), of ('or'), ... These are all particles and coordinating conjunctions that have an "additive" or appositional meaning. Any scholar who has studied Leeuwen's works will immediately agree that these words are indeed typical of Leeuwen's writing style: Leeuwen adopts a very spontaneous, stream-of-consciousness-like writing style where one thought always builds upon the previous.

\section{[Fig. 5]}

Another fascinating, yet slightly less obvious feature is that a number of stylistic oppositions are revealed between these two authors on the level of prepositions: Ruusbroec seems to have a clear preference for the preposition in ('in', to the far right), whereas Leeuwen tends to favour the use of binnen ('inside', barely readable, in the upper-left quadrant). It is intriguing that, in addition, we can find the (although slightly less outspoken) corresponding pair buiten ('outside', close to binnen) and uit ('out'). This strongly suggests that Ruusbroec prefers to use the pair in-out in antithetical arguments in his texts, whereas Leeuwen is more comfortable using binnen-buiten. Such stylistic oppositions seem fairly subconscious stylistic choices and can more be connected with authorial habits, rather than genre-related conventions.

\section{The Twelve Virtues}

Now that we have demonstrated our methodology on a corpus of relatively undisputed provenance, it is interesting to extent our analyses to two longer works from the Groenendaal tradition of which the authorship continues to confuse scholars. In this context, it is interesting to refer to On the Twelve Virtues (Van den XII dogheden). ${ }^{42}$ This anonymous text is traditionally considered a relatively free adaptation of the influential Reden der Unterweisung by Master Eckhart, although the first four chapters draw on Ruusbroec's Spiritual Espousals. Importantly, the Virtues also seem partially dependent on small parts of a pre-existing Middle Dutch adaptation of the Reden. ${ }^{43}$ Because of the undeniable Ruusbroec-like aspects of the text, it does not come as a surprise perhaps that, until well into the past century, researchers have struggled with the possibility that the Virtues should be ascribed to Ruusbroec. In fact, it is striking that the text has even been edited in 1932 amongst Ruusbroec's works in an influential, yet presently outdated edition. ${ }^{44}$

The Virtues are moreover listed among Ruusbroec's works in a number of manuscripts, inclusing BRUSSELS, ROYAL LIBRARY, MS 3416-24, an authoritative Ruusbroec-miscellany. ${ }^{45}$ Presently, however, the attribution of the Virtues to 
Ruusbroec seems to be quasi-universally rejected, although it should be noted that the debate on this topic among authorative experts has continued for long. ${ }^{46}$ A major textexternal argument in this respect only came to light quite recently (after Van Mierlo has already argued against the Ruusbroec attribution): in a one Eastern Frankish manuscript of the Virtues the text is attributed to a named author: Hier begynet das buch von den zwolff dogenden des geistlichen herren Godeverdes, regulers canonikes in dem closter grunendale. ${ }^{47}$ Scholars have rushed to identify this author as Godfried van Wevel (died in 1396) who between 1355 and 1350 became the first regular canon in the Groenendaal community. Afterwards, this Godefridus dictus Wevel (ca. 13771381) became the prior and novice master at the new foundation in Eemstein, although it is known that he has returned to Groenendaal after his stay in Eemstein. Possibly, his work was written for the novices in Eemstein so that the Virtues might in fact post-date Wevel's first Groenendaal period. ${ }^{48}$ Unfortunately, no other texts survive that can be attributed to Wevel on firm grounds. Fraeters, for instance, continued to address the Virtues' author as 'pseudo-Ruusbroec'. ${ }^{49}$ The text can therefore serve as an interesting test case in our attribution experiments. This case is especially worthwile, because the first part of the Virtues draws upon the writings of Ruusbroec, which might make it difficult to discriminate between Ruusbroec's style and that of his epigone. This stylistic arguments which have raised so far by for instance Van Mierlo have remained fairly non-commital and impressionistic. Importantly, the stylistic discussion has been limited to the level on content words, such as the adverb eenpaerlic ('unrelenting'), which Van Mierlo deemed common in the Virtues, but uncharacteristic of Ruusbroec. ${ }^{50}$ It would be interesting to assess, therefore, how distant the text is from Ruusbroec's works when it comes to function words.

For the next experiments we select as sample size 3,971 lemmas, the size of Ruusbroec's shortest text (The Four Temptations). For the sake of clarity, I will indicate the author of the Virtues with the authorial label 'Wevel'. The Virtues amounts to 27,084 lemmas. In Fig. 6 we show the result of an HC comparing Ruusbroec's oeuvre and the Virtues with a sample size of 3,971 lemmas. In Fig. 7 we have performed a similar PCA, of which the loadings are plotted in Fig. 8. These plots clearly shows the stylistic distance between Ruusbroec's oeuvre and the Virtues. While Ruusbroec's oeuvre does contain a good deal of important internal stylistic variation, it is clear that the stylistic distances between his texts are hardly comparable to the difference between the Virtues and Ruusbroec's works. The loadings in Fig. 8 again prove insightful: in ('in') and met ('with') again seem words favoured by Ruusbroec. The Virtues, on the other hand, stand out because of the elevated use of words that e.g. seem related to comparisons and quantification: meer ('much'), beter ('better'), meest ('most'), veel ('much') or dan ('than'). Another interesting word that seems to reflect an unconscious stylistic preference of Wevel's concerns the contentpoor conjunction want ('because'), which apparently is used much less frequently in Ruusbroec's texts.

[Fig. 6]

[Fig. 7]

[Fig. 8]

This clear difference is especially remarkable in the light of previous research, because many scholars have noted how Wevel is indebted to Ruusbroec in the second 
part of the Virtues. Apparantly, this indebtedness has not caused a noticable artificial increase in stylistic similarity between these two texts. This result thus offers additional quantitative support for the hypothesis formulated by traditional scholars that Ruusbroec did not author this text in spite of some misguided attributions in later manuscripts. Fig. 9, finally, shows an analysis in which we have included some of Leeuwen's texts, but only those with 6,330 lemmas. Interestingly, the difference between Leeuwen and Ruusbroec is captured in the first, horizontal component (i.e. the left-right opposition), whereas the difference between Ruusbroec and Wevel is reflected in the vertical component (i.e. the upper-left quadrant versus the lower-left quadrant). The even larger distance between between Leeuwen and Wevel show that Leeuwen too is an extremely unlikely authorial candidate for the Virtues.

\section{[Fig. 9]}

\section{The Mouth-Kiss}

A second interesting test case is The Mystical Mouth-Kiss (De osculo oris), a Middle Dutch mystical text which is nowadays considered nothing less than a pièce de résistance in the Middle Dutch mystical tradition. ${ }^{51}$ The text is anonymous and only survives under a Latin title (De oris osculo). Scholars have therefore wondered whether the text is indeed originally Middle Dutch - although no Latin source text has been identified either. The author of The Mouth-Kiss is inspired by the well-known theme of the gradi ad amorem: the respective stages of seeing, speaking, touching and kissing God. The final stage of kissing is divided in the respective phases of kissing of the feet, hands and mouth, to describe the human soul's progress towards the mystical encounter with God. The text opens with an evocative allusion to the Song of Songs: 'may He kiss me with the kisses of His mouth'.

The text's first editor, the late father Reypens, has proposed to attribute the MouthKiss to Willem Jordaens (ca. 1321-1372), a well-known collaborator of Ruusbroec's in Groenendaal. Jordaens is known to have produced Latin texts in Groenendaal and is nowadays particularly well-known for his Latin translations of (at least) three of Ruusbroec's vernacular works. ${ }^{52}$ The attribution of the Mouth-Kiss is nevertheless highly problematic, primarily because Jordaens is nowhere listed as an author of Middle Dutch texts. No historic references to the Mouth-Kiss moreover survive from Groenendaal, let alone an attribution, which is surprising, given the positive criticism which the text nowadays invites. A major difficulty is that scholars have stressed that, while the Mouth-Kiss is thematically clearly related to Ruusbroec's writings, a number of important divergences emerge on the level of teaching. Scholars like Schepers have raised the question, if Jordaens was indeed the author of the MouthKiss, the work would not have been written before Jordaens joined the Groenendaal community. ${ }^{53}$ The underlying assumption is that Jordaens would have been unable to produce such a divergent text, after or during his intensive contacts with Ruusbroec in Groenendaal. While Ruusbroec has never been considered as the author behind the Mouth-Kiss, it proves interesting below to confront this text with the other Groenendaal texts.

In Fig. 10 we have plotted the results of a PCA on samples from Ruusbroec's oeuvres with samples from the Mouth-Kiss (again, for a sample size of 3,971). While samples from the Mouth-Kiss cluster in one quadrant, it is immediately clear that it is much more similar to Ruusbroec's texts, than was the case for Wevel or Leeuwen. A 
number of samples drawn from the end of Ruusbroec's Tabernacle, for instance, come suprisingly close. These advanced similarities are intriguing because Jordaens is known to have translated Ruusbroec's Tabernacle into Latin (De spirituali tabernaculo), although this translation does not survive. When it comes to Jordaens and Ruusbroec, it is interesting that we only obtain a clearer separation when we confront the Mouth-Kiss with subportions of Ruusbroec's oeuvre, especially if we exclude the Tabernacle (a long and complex text which devours a lot of the variation in the plots).

[Fig. 10]

This is confirmed by the cluster analysis in Fig. 11 and the bootstrap tree in Fig. 12, which leave out the Tabernacle and thus obtain a much better split. This suggests a number of interesting things: first of all, we seem to reach the limits of our visualisation methods: apparantly, it is difficult, for instance for a PCA, to visualize both the considerable variation in Ruusbroec's entire oeuvre and set it apart from the Mouth-Kiss. Especially the closing sections of the latter text are remarkably close to Ruusbroec in style. This does not come as a surprise, since this part of the Mouth-Kiss is much more heavily concerned with typical mystical themes. ${ }^{54}$ Secondly, this situation indirectly seems to strenghten Jordaens's profile as author of the MouthKiss, an attribution for which in fact no hard proof exists. As Ruusbroec's close collaborator and translator, Jordaens must have been deeply familiar with Ruusbroec's Middle Dutch oeuvre: the fact that the Mouth-Kiss too is so similar in style to Ruusbroec, does indeed suggest that the author of the Mouth-Kiss must have been someone thoroughly aquainted with Ruusbroec's style, such as his translator Jordaens.

[Fig. 11]

[Fig. 12]

We should emphasize, however, that an important conflict emerges here between our findings and previous studies of Jordaens. Schepers, following Reypens, has stressed that the Mouth-Kiss shows no clear signs of being thematically influenced by Ruusbroec's teachings. He in fact wonders whether Jordaens - if he is indeed the author of this text - wrote this text in Groenendaal and stresses that Jordaens might just as well have written this text in his youth, before joining the Groenendaal community. ${ }^{55}$ It is fascinating, but as yet difficult to assess, that the stylistic proximity between Ruusbroec and Jordaens on the level of function words, suggests the exact opposite, namely that Ruusbroec might have had an important stylistic influence on Jordaens.

Whatever be of this, it is possible to point towards some interesting differences in style between Ruusbroec's texts and the Mouth-Kiss. In Fig. 13 we have plotted the word loadings for the same analyses as Fig. 11 and 12 (i.e. excluding the Tabernacle). An number of interesting features can be discerned. To the far left we find the coordinating conjunction en. Based on our previous comparisons above, I am not so much inclined to think that Ruusbroec now suddenly makes extensive use of this word; rather, it is seems like it the author of the Mouth-Kiss who carefully avoids this common connector. On the far left, we find a whole battery of other conjunction-like items that the author of the Mouth-Kiss seems to use as alternatives for connecting 
and stacking sentences: daarom ('therefore'), omdat ('because'), nochtans ('nevertheless'), overmits ('since'), ... Another remarkable feature is the adposition te ('to') to the far right, which might indicate that the author of the Mouth-Kiss, much more than Ruusbroec, favoured infinitival constructions ( $t e+$ infinitive).

[Fig. 13]

Finally, we can use the confrontation between Ruusbroec and Jordaens to illustrate the surplus value of working with function works in this corpus. Fig. 14 has been generated on the exact same texts as Figs. 10, but this time, we have not limited our PCA to a carefully selected list of high-frequency words. Instead, we have simply used the 1,000 most frequent items in these texts, which will obviously include a many content words. As can be gleaned from Fig. 14, the distinction between Ruusbroec and the Mouth-Kiss - which was already faint - has now disappeared entirely: in fact, the samples drawn from the Mouth-Kiss now indistinguishably mingle with Ruusbroec's works. Moreover, the internal stylistic coherence of Ruusbroec's oeuvre seems to have been considerably weakened. This does not come as a surprise: the variety of content words included in this analysis will cause Ruusbroec's works to display much larger stylistic divergences. Moreover, because the Mouth-Kiss and other of Ruusbroec's texts discuss such strongly related themes and topic, content words will moreover introduce artificial similarities in writing style between them. The comparison of Fig. 13 versus Fig. 11 clearly illustrates the surplus value of working with function words for the study of the authorial writing style in these texts.

[Fig. 14]

\section{Conclusion}

In this paper I hope to have demonstrated the potential of applying Distant Reading techniques from stylometry to a corpus of medieval Dutch literature from the Low Countries. Authorship attribution, in particular, is an application from stylometry from which medieval studies might benefit a lot, even in the near future. While stylometric authorship attribution has been applied to medieval literature before, serious concerns have been raised as to how to deal with the textual variation found in the material, of the substantive, as well as the accidental kind. I hope to have convincingly argued that stylometry can indeed yield valid results for authorship attribution in the study of medieval prose literature, when it is carefully combined with research results obtained by traditional philological analysis. While Ruusbroec's Groenendaal contemporaries must have been deeply influenced by the charismatic master, we have pointed to a least a number of cases in which algorithms have few problems in separating Ruusbroec from close colleagues on the basis of function words.

Stylistically, speaking Leeuwen and Ruusbroec, for instance, are worlds apart: our analyses far from suggest that Ruusbroec had a deterministic, measurable stylistic influence on Leeuwen's writings in the form they survive. From our results, Leeuwen generally emerges as an independent author, at least on the level of writing style. Moreover, none of the redaction phases which can be discerned on the codicological level in Leeuwen's oeuvre show a clear-cut correlation with differences in the writing style of these texts. When it comes to the disputed texts analyzed in this paper, a 
number of interesting stylistic observations can be made that challenge our understanding of this literature. When it comes to The Twelve Virtues our analyses suggest that the writing style of this work is dissimilar from Ruusbroec's style, even though the text borrows from Ruusbroec's Espousals, which reveals a fascinating tension between content and style. Our algorithms clearly side with the current stateof-the-art in Ruusbroec scholarship and support the claim that Ruusbroec is an extremely unlikely authorial candidate for this text. If the mysterious Godfried van Wevel indeed authored this text, as one later attribution seems to claim, the considerable stylistic distance might in fact support the hypothesis that this text postdates Wevel's first Groenendaal period. Situating the production of this text in Wevel's later Eemsteyn period, as for instance Scheepsma suggests, might very well help to explain the divergences on the level of style. ${ }^{56}$

Quite the opposite seems true for the Mouth-Kiss: while this work is much more independent from Ruusbroec on the level of mystical teaching, the style of the text corresponds much more closely to Ruusbroec's oeuvre, than the Twelve Virtues does. The stylistic affinities between Ruusbroec and the Mouth-Kiss might suggest an author which was deeply familiar with Ruusbroec's writing style: both authors say different things, yet seem to adopt similar styles to do so. Such a deep stylistic familiarity could well be expected from a translator like Jordaens, who collaborated so intensively with Ruusbroec in Groenendaal. An important conflict neverthless emerges with previous scholarship which has argued on the basis of content-level differences, that the Mouth-Kiss pre-dates Jordaens's Groenendaal period. ${ }^{57}$

Perhaps it is time to re-assess this viewpoint: Groenendaal authors like Leeuwen have been primarily studied as disciples of Ruusbroec, but less as independent authors in their own right. Current scholarship, nevertheless increasingly stresses the high contemporary status which authors like van Leeuwen must have held. The richly decorated manuscripts of Leeuwen, featuring for instance full-page authorial depictions (a rarity in Middle Dutch literature), do not suggest that other Groenendaal authors were all docile followers of Ruusbroec, unable to develop their own, perhaps even deviant views. ${ }^{58}$ I therefore see no reason to exclude the possibility that an established author like Jordaens was able to develop an independent line of thought within the Groenendaal community. All in all, these closing observations hopefully illustrate the kind of scientific serendipity which stylometry might induce in literary studies: when adopting a different perspective, our analyses suggest textual affinities that resist and challenge conventional characterizations in traditional philology.

\section{Acknowledgements}

I would like to thank Ine Kiekens, Thom Mertens, Kees Schepers and Frank Willaert for their thorough feedback on earlier versions of this paper. My gratitude also goes out to Dirk Geirnaert who provided me with a diplomatic transcription of Jan van Leeuwen's oeuvre: without this data, this paper could simply not have been written. I also thank Frans de Jonge (University of Antwerp) for his help in the practical preparations for this paper.

\section{Academic biography}

Mike Kestemont currently is a researcher at the University of Antwerp (Belgium), working on a postdoctoral grant of the Research Foundation of Flanders. Mike enjoys 
research in the Digital Humanities, in particular authorship attribution in historic texts, such as Middle Dutch literature. Much of his work can be situated in the "Digital Humanities".

\section{Address}

Postal: University of Antwerp, City Campus D.118, Grote Kauwenberg 18, B-2000 Antwerp, Belgium

Mobile: 0032477918668

Email: mike.kestemont@uantwerp.be

${ }^{1}$ A recent survey on the problem of authorship attribution in general can be found in: Harold Love,
Authorship Attribution. An Introduction (Cambridge, UK, 2002).
${ }^{2}$ A collection of introductory papers on Digital Humanities is: A Companion to Digital Humanities,
ed. Susan Schreibman, Ray Siemens and John Unsworth (Oxford, 2004). More specific introductory
references on (the history of) stylometry and authorship attribution are: David I. Holmes, 'Authorship
attribution', Computers and the Humanities 28 (1994), pp. 87-106; David I. Holmes, 'The evolution of
stylometry in Humanities scholarship', Literary and Linguistic Computing 13 (1998), pp. 111-117;
Mike Kestemont, 'What can stylometry learn from its application to Middle Dutch literature?', Journal of Dutch Literature 2 (2011), pp. 46-65 (specifically for medieval literature).

${ }^{3} \mathrm{~A}$ interesting reference is this respect is the recent special issue of the Tijdschrift voor Nederlandse Taal- en Letterkunde (2013) 129, nr. 4, on computational approaches in Dutch literary studies. A representative sample of recent English-language papers on medieval stylometry specifically is: Karina van Dalen-Oskam \& Joris van Zundert, 'Delta for Middle Dutch - Author and Copyist Distinction in Walewein', Literary and Linguistic Computing 22 (2007), pp. 345-362 (Middle Dutch); Jan M. Ziolkowski, 'Lost and not Yet Found: Heloise, Abelard and the Epistolae duorum amantium', Journal of Medieval Latin 14 (2004), pp. 171-202 (Medieval Latin); Michael Treschow, Paramjit Gill and Tim B. Swartz, 'King Alfred's Scholarly Writings and the Authorship of the First Fifty Prose Psalms', The Heroic Age (2009), s.p. [http://www.heroicage.org/issues/12/treschowgillswartz.php, last accessed 23/10/2014] (Old English); Brian J. Reilly and Moira R. Dillon, 'Virtuous Circles of Authorship Attribution through Quantitative Analysis: Chrétien de Troyes's Lancelot', Digital Philology 2 (2013), pp. $60-85$.

${ }^{4}$ A well-received Dutch-language introduction is offered in the recent history of fourteenth-century Middle Dutch literature in Frits van Oostrom, Wereld in woorden. Geschiedenis van de Nederlandse literatuur 1300-1400, Geschiedenis van de Nederlandse literatuur [2] (Amsterdam 2013), p. 242-281.

${ }^{5}$ A landmark in the recent scholarship on Jan van Ruusbroec (as well as the early Groenendaal community in general) has been the publication of a English-language survey monograph to which I am greatly indebted, especially in the following paragraphs: A Companion to John of Ruusbroec, ed. John Arblaster and Rob Faesen, Brill's Companions to the Christian tradition 51 (Leyden, 2014). This volume is a wonderful addition to Ruusbroec's opera omnia which were already available in an authoritative series of critical editions and English translations in Brepols's Corpus Christianorum Continuatio Mediaevalis series. For a highly readable biography on Ruusbroec, see Geert Warnar, Ruusbroec. Literature and mysticism in the fourteenth century (Leyden, 2007).

${ }^{6}$ For the impact of Ruusbroec in translation, see Van Oostrom, Wereld in woorden, p. 272.

${ }^{7}$ E.g. Bernard McGinn, The Varieties of Vernacular Mysticism (1350-1550), The Presence of God. A History of Western Christian Mysticism 5 (New York), p. 9.

${ }^{8}$ His oeuvre also includes a series of shorter letters which unfortunately only survive partially in Middle Dutch excerpts and in Latin translation. Other shorter texts (e.g. songs) that have sometimes been attributed to Ruusbroec are too short to be included here.

${ }^{9}$ Van Oostrom, Wereld in woorden, p. 242 and pp. 278-281.

${ }^{10}$ McGinn, Varieties, p. 2.

${ }^{11}$ Recent scholarship on Leeuwen has focused on his decalogical tractates as well as his eschatological thinking. Relevant references include Joris Reynaert, 'Met de zodiak op drift. Structuur en 'stemmen' in Jan van Leeuwens 'Vanden seven teekenen der sonnen", Queeste 12 (2005), pp. 97-126 (with occasional remarks on Leeuwen's style); Youri Desplenter, 'Huis-tuin-en-keukenmoraal? Jan van Leeuwen en de 10 geboden', Spiegel der Letteren 52 (2010), pp. 1-29; Ulrike Wuttke, 'Dit es dinde van goede en quade'. Eschatologie bei den Brabanter Autoren Jan van Boendale, Lodewijk van Velthem und Jan van Leeuwen (14. Jh.) (Unpublished PhD thesis Ghent University, 2012). 
${ }_{13}^{12}$ See Van Oostrom, Wereld in woorden, p. 256-257.

${ }^{13}$ A seminal contribution on the manuscript tradition of Leeuwen is: Dirk Geirnaert and Joris Reynaert, 'Geestelijke spijs met zalige vermaning. Verspreiding, overlevering en receptie van Jan van Leeuwen', in Boeken voor de eeuwigheid. Middelnederlands geestelijk proza, ed. T. Mertens et al (Amsterdam, 1993), pp. 190-209 and pp. 426-436. Note that in a forthcoming publication Desplenter and Vandemeulebroucke will argue against the distinction of the first and second redaction phase discussed below (which is also in line with the stylometric results reported here): Youri Desplenter and Eva Vandemeulebroucke, 'How Jan van Leeuwen $(\dagger 1378)$ was made an author. Opera omnia and authority', in Shaping Authority (Brepols, forthcoming in 2014). The authors also seem more reserved with respect to the level of changes applied in these redaction phases and consider these 'fairly limited'. Apart from the fairly obvious addition of chapter divisions headings, the editorial interventions primarily seem to have involved the deletion of passages, which obviously has little impact of the overall style of the texts. I thank the authors for sharing a preliminary version of this paper with me.

${ }^{14}$ See Geirnaert and Reynaert, 'Geestelijke spijs', passim, but also Desplenter, 'Huis-tuin-enkeukenmoraal', pp. 10 (n. 25).

${ }^{15}$ Geirnaert and Reynaert, 'Geestelijke spijs', pp. 200.

${ }^{16}$ Geirnaert and Reynaert, 'Geestelijke spijs', pp. 201.

${ }^{17}$ Recent technical survey papers include Efstathios Stamatatos, 'A Survey of Modern Authorship Attribution Methods', Journal of the American Society for Information Science and Technology 57 (2006), pp. 753-767; Moshe Koppel, Jonathan Schler and Shlomo Argamon, 'Computational Methods in Authorship Attribution', Journal of the American Society for Information Science and Technology 60 (2008), pp. 9-26; Patrick Juola, 'Authorship Attribution', Foundations and Trends in Information Retrieval 1 (2006), pp. 233-334.

${ }^{18}$ An interesting recent paper in the field of stylochronometry is: David L. Hoover, 'A Conversation Among Himselves. Change and the Styles of Henry James, in Digital Literary Studies. Corpus Approaches to Poetry, Prose, and Drama, ed. David L. Hoover, Jonathan Culpeper and Kieran O'Halloran, Foreign Language Study 16 (New York, 2014), pp. 64-89.

${ }^{19}$ Important theoretical studies on 'Distant Reading' include: Matthew G. Kirschenbaum, 'The Remaking of Reading: Data Mining and the Digital Humanities', in The National Science Foundation Symposium on Next Generation of Data Mining and Cyber-Enabled Discovery for Innovation, (Baltimore, 2007), s.p.; Franco Moretti, Distant Reading (London, 2013); Matthew Jockers, Macroanalysis. Digital Methods and Literary History (Urbana, 2013).

${ }^{20}$ Stamatatos, 'Survey', 2009, p. 538.

${ }^{21}$ A good example in the context of the Apuleian corpus in classical studies is: Josef Redfors, Echtheitskritische Untersuchung der apuleischen Schriften De Platone und De Mundo (Lund, 1960).

${ }^{22}$ A recent survey on the use of function words for authorship attribution: Mike Kestemont, 'Function Words in Authorship Attribution. From Black Magic to Theory?', in Proceedings of the Third Computational Linguistics for Literature Workshop, ed. Anna Feldman, Anna Kazantseva and Stan Szpakowicz (Gothenburg, 2014), pp. 59-66. Slightly older, yet still very relevant is: José Nilo G. Binogo, 'Who Wrote the 15th Book of Oz? An Application of Multivariate Analysis to Authorship Attribution', Chance 16 (2003), pp. 9-17.

${ }^{23}$ A relevant illustration are the secretaries working with Vincent of Beauvais (e.g. Antoine Dondaine, Le dominicaine français Jean de Mailly et la legende dorée, Archives d'histoire dominicaine 1, pp. 53102) or Bernard of Clairvaux (see e.g. Jean Leclercq, 'Saint Bernard et ses secretaires', in Recueil d'études sur Saint Bernard et ses écrits. Vol. 1 (Rome, 1962), pp. 3-25), who might well have been specifically trained to imitate the style of their masters. A stylometric study of some of the secretaries of Hildegard of Bingen is: Mike Kestemont, Sara Moens and Jeroen Deploige, 'Collaborative authorship in the twelfth century: A stylometric study of Hildegard of Bingen and Guibert of Gembloux', Literary and Linguistic Computing (2013), DOI: 10.1093/llc/fqt063 [in press].

${ }^{24}$ See e.g. Richard Wollheim, On Art and the Mind. Essays and Lectures (Cambridge, MA, 1972), p. $177 \mathrm{ff}$.

${ }^{25}$ See e.g. Mike Kestemont and Karina van Dalen-Oskam, 'Predicting the past: memory-based copyist and author discrimination in medieval epics', in Proceedings of the twenty-first Benelux conference on artificial intelligence, ed. Toon Calders, Karl Tuyls and Mykola Pechenizkiy (Eindhoven, 2009), pp. 121-128.

${ }^{26}$ General references include Michael Benskin and Margaret Laing, 'Translations and Mischsprachen in Middle English manuscripts', in So meny People, Longages, and Tonges. Philological essays in Scots and mediaeval English presented to Angus McIntosh, ed. Michael Benskin and Michael L. 
Samuels (Edinburgh, 1981), pp. 55-106 (Middle English); Gabriella Parussa, Richard Trachsler, Yvonne Cazal and Cinzia Pignatelli, 'L'orthographe: du manuscrit médiéval à la linguistique moderne', Medievales: Langue, textes, histoire 45 (2003), pp. 99-117 (Middle French); Mike Kestemont \& Elisabeth De Bruijn, 'Contrastive Multivariate Analyses of the Middle Low German Flos unde Blankeflos tradition', Neuphilologische Mitteilungen 114 (2013), pp. 171-205 (Middle Low German).

${ }^{27}$ Van Dalen-Oskam and Van Zundert, 'Delta for Middle Dutch', passim.

${ }^{28}$ See Daniel Jurafsky and James H. Martin, Speech and Language Processing. An Introduction to Natural Language Processing, Computational Linguistics and Speech Recognition (Englewood Cliffs, 2000), pp. 285-318.

${ }^{29}$ The work for this lemmatiser builds upon the following publication (where the task of lemmatisation is introduced in more detail): Mike Kestemont, Guy de Pauw and Walter Daelemans, 'Weigh your words - Memory-Based Lemmatization for Middle Dutch', Literary and Linguistic Computing 25 (2010), pp. 287-301.

${ }^{30}$ See e.g. Mike Kestemont, 'Kestemont, M., ‘Arthur's Authors. A Quantitative Study of the Rhyme Words in the Middle Dutch Arthurian Epic', Zeitschrift für deutsches Altertum und deutsche Literatur 142 (2013), pp. 1-33.

${ }^{31}$ See e.g. the various rhyme-related constraints discussed in David C. Rubin, Memory in Oral Traditions. The Cognitive Psychology of Epics, Ballads, and Counting-out Rhymes (New York, 1995).

${ }^{32}$ See e.g. M. Kestemont, 'Stylometry for Medieval Authorship Studies: An Application to Rhyme Words?, Digital Philology 1 (2012), pp. 42-72. Contributions on the prevalence of rhyme in the Middle Dutch tradition include Orlanda S.H. Lie, 'What is Truth? The Verse-Prose Debate in Medieval Dutch Literature', Queeste 1 (1994), pp. 34-65 and more recently: Bart Besamuca, 'The Prevalence of Verse in Medieval Dutch and English Arthurian Fiction', Journal of English and Germanic philology 112 (2013), pp. 461-474.

${ }^{33}$ The software used for this paper is the free statistics package 'Stylometry with R', which is discussed in the following poster abstract: Maciej Eder, Mike Kestemont and Jan Rybicki, 'Stylometry with R: a suite of tools', in Digital Humanities 2013. Conference abstract (Lincoln, 2013), pp. 487-489. More information on these techniques can be found in the manual available from the developing group's website: https://sites.google.com/site/computationalstylistics/ [last accessed 26/09/2014]. In all experiments, I use this package's standard parameters, unless specified otherwise.

${ }^{34}$ A seminal publication on the use of cluster analyses in stylometry is: David L. Hoover, 'Multivariate analysis and the study of style variation. Literary and Linguistic Computing 18 (2003), pp. 341-360. Most the techniques in present-day quantitative literary studies have been initiated in some form or the other in the pioneering monograph: John F. Burrows, Computation into Criticism. A Study of Jane Austen's novels (Oxford, 1987). Burrows is often considered one of the founding fathers of stylometry: one of his most recent pieces offers a number of interesting (polemic) reflections on recent developments in the field: John F. Burrows, 'A Second Opinion on "Shakespeare and Authorship Studies in the Twenty-First Century", Shakespeare Quarterly 63 (2012), pp. 355-92.

${ }^{35}$ Although we could have included the part-of-speech information outputted by our tagger-lemmatiser, our results below show that part-of-speech tags do not seem essential to obtaining solid attribution results, which is why we have left them out for the sake of clarity

${ }^{36}$ Introduced in: John F. Burrows, 'Delta': a Measure of Stylistic Difference and a Guide to Likely Authorship', Literary and Linguistic Computing 17 (2002), pp. 267-287. For a theoretical discussion, see: Shlomo Argamon, 'Interpreting Burrows's Delta: Geometric and Probabilistic Foundations', Literary and Linguistic Computing 23 (2008), pp. 131-147.

${ }^{37}$ This technique has been ported to stylometry in: Maciej Eder, 'Computational stylistics and Biblical translation: how reliable can a dendrogram be?', in The translator and the computer, ed. Piotrowski, Tadeusz \& Łukasz Grabowski (Wrocław, 2013), p. 155-170.

${ }^{38}$ Technical note about the BTC: we used the standard parameters of the stylo-function, with the 30 MFW to the $150 \mathrm{MFW}$, with a step size of 10 .

${ }^{39}$ Geinaert and Reynaert, 'Geestelijke spijs', p. 200: 'Maar ook al zou men niet zover gaan te veronderstellen dat Van Leeuwens werken van meet af aan door een (of meer) andere(n) werden herschreven of dat hem door het klooster een secretaris bij wijze van ghostwriter ter beschikking zou zijn gesteld, duidelijk is alvast dat Groenendaal vanaf de vroegste verspreiding in geschreven vorm de zaken stevig in handen heeft genomen. Voor de eerste 'editie' [i.e. Le1, MK] zou dan bijvoorbeeld aan Ruusbroec, voor de tweede [i.e. Le2, MK] aan Jan van Schoonhoven [i.e. a local Groenendaal monk, $\mathrm{MK}]$ kunnen worden gedacht.' 
${ }^{40}$ E.g. Kestemont, Moens and Deploige, 'Collaborative authorship'. A similar paper is: Noel B. Reynolds, G. Bruce Schaalje and John L. Hilton, 'Who wrote Bacon? Assessing the respective roles of Francis Bacon and his secretaries in the production of his English Works', Literary and Linguistic Computing 27 (2012), pp. 409-425.

${ }^{41}$ For an introduction to PCA in the context of authorship attribution, see e.g. Binongo, 'Who Wrote'. The same technique is used for scribal analyses in Kestemont and De Bruijn, 'Contrastive Multivariate Analyses'.

${ }^{42}$ A recent state-of-art and bibliography are offered in Kurt Ruh, Geschichte der abendländischen Mystik. Die niederländische Mystik des 14. bis 16. Jahrhunderts. Vol. 4 (Munich, 1999), pp. 118-123. A more recent survey (with new hypotheses) in: Wybren Scheepsma, 'Das mittelniederländische Nachleben der Erfurter "Reden" Meister Eckharts', in Meister Eckharts Erfurter Reden in ihrem Kontext, ed. Dagmar Gottschall and Dietmar Miet, Meister-Eckhart-Jahrbuch 6 (Stuttgart, 2013), pp. 131-151.

${ }^{43}$ A recent discussion is offered by Scheepsma, 'Das mittelniederländische Nachleben', especially $p$. 138-145. Dra. Ine Kiekens (University of Ghent/University of Antwerp) is currently preparing a dissertation on the Twelve Virtues and she emphasized that Ruusbroec's influence in the first part might have been over-estimated in traditional scholarship, especially because Eckhard's influence too can already be discerned in the Virtues from the second chapter onwards.

${ }^{44}$ Jan van Ruusbroec, Werken. Deel 3: Vanden XII dogheden, Een spieghel der ewigher salicheit, Vanden kerstenen ghelove, ed. Jean Baptiste David (Ghent, 1860).

${ }^{45}$ These manuscripts are discussed in Robrecht Lievens, 'Wie schreef de "XII dogheden'?', Verslagen en mededelingen van de Koninklijke Vlaamse Academie voor Taal-en Letterkunde (1960), pp. 233237.

${ }^{46}$ See e.g. the major polemic between Bouman en Van Mierlo, e.g. Jozef van Mierlo, 'De XII Dogheden geen werk van Ruysbroeck', Tijdschrift voor Nederlandse Taal- en Letterkunde 44 (1925), pp. 165-184.

${ }^{47}$ Cited after Scheepsma, 'Das mittelniederländische Nachleben', p. 140. The manuscript is BERLIN, StaAtsbibliotheK Zu Berlin, Preussischer Kulturbesitz, Ms. Germ. OCt. 478 (f. 148v).

${ }^{48}$ On Wevel and Eemsteyn, see Scheepsma, 'Das mittelniederländische Nachleben', e.g. p. 144.

${ }^{49}$ Veerle Fraeters, 'De fabricatie van een tekst. Toe-eigeningsmechanismen in tekst en traditie van pseudo-Ruusbroecs Vanden twaelf dogheden', Volkskunde 104 (2003), pp. 85-104.

${ }^{50}$ Van Mierlo, 'De XII Dogheden', p. 184.

${ }^{51}$ The most important recent contributions to the study of Jordaens are: Kees Schepers, 'Willem Jordaens. Auteur en vertaler', Ons Geestelijk Erf 78 (2004), pp. 31-51. A bibliography and state of the art are offered in Ruh, Geschichte, p. 83-99.

${ }^{52}$ A well-known passage from Ruusbroec's biography is that ca. 15 years after his death, Jean Gerson, chancellor at the University of Paris, would question the orthodoxy of the last past of Ruusbroec's The Spiritual Espousals. Here Ruusbroec spoke in controversial wordings about the union of the human person and God 'without difference' (sonder differentie). Gerson knew this text only in Jordaens's Latin translation. See Schepers, 'Willem Jordaens', pp. 35-36.

${ }^{53}$ Schepers, 'Willem Jordaens', p. 46.

${ }^{54}$ Van den geesteliken tabernakel, Vol. 1, ed. Thom Mertens, Jan van Ruusbroec. Opera omnia 5 (Turnhout, 2006), p. 26.

${ }^{55}$ Schepers, 'Willem Jordaens', p. 46.

${ }^{56}$ Scheepsma, 'Das mittelniederländische Nachleben', p. 142.

${ }^{57}$ Note that Schepers's own observations to some extent contradict this assumption: Schepers lists a number of additions to the Mouth-Kiss that seem directly inspired by passages from Jordaens's translation of the Espousals. Unless we assume that the author added these references in a later revision, this strongly suggests that Jordaens had already translated Ruusbroec before composing the Mouth-Kiss.

${ }^{58}$ Desplenter and Vandemeulebroucke (cf. supra) also stress the considerable respect and veneration which Leeuwen must have enjoyed in Groenendaal (perhaps even a status which was comparable to that of Ruusbroec). 